\title{
REVISITING THE BENEFITS OF ANIMAL TRACTION TO SUBSISTENCE SMALLHOLDER FARMERS: A CASE STUDY OF NDABAKAZI VILLAGES IN BUTTERWORTH, EASTERN CAPE PROVINCE OF SOUTH AFRICA
}

\author{
Zantsi, S. ${ }^{1}$ and Bester, B. ${ }^{2}$
}

Correspondence author: S. Zantsi. Email: siphezantsi@yahoo.com

\begin{abstract}
Animal traction has long been a pillar of agricultural production up until the invention of mechanical power which diverted attention to modern mechanical power and led to many perceiving it as backwards, irrelevant and less important. The objective of this article is to relate the known, but forgotten, benefits of animal traction to smallholder farming by presenting evidence of how these benefits still relate to subsistence smallholders using a case study of Ndabakazi villages in the Eastern Cape Province of South Africa. Primary data were drawn from a sample of 80 subsistence farming households. These were randomly selected and a semi-structured questionnaire was administered using a local language. Focus group discussions were used to supplement the questionnaire. The overall finding is that animal traction is indeed still relevant to subsistence farming households. It cuts arable production costs relating mainly to ploughing, planting and weeding, which are the major costly activities. Finally, the adoption of donkeys, horses and mules is recommended, since cattle are not widely kept. Moreover, cattle are labour intensive compared to the recommended animals.
\end{abstract}

Keywords: Animal traction, Butterworth, Eastern Cape, Subsistence farmers

\section{INTRODUCTION}

Smallholder subsistence farming is a dominant form of household agricultural activity in South Africa, practiced by more than two million households representing about four million individuals (Statistics South Africa (StatsSA), 2007; StatsSA, 2016). Despite its low productivity and many negative perceptions, it makes at least some contribution to household food security at little effort and low risk (Aliber \& Hart, 2009). In this respect, there is recent evidence that poor rural households experience less hunger than their non-farming poor counterparts (Rogan \& Reynolds, 2018).

In the last two decades, the support measures given to subsistence farmers have achieved very little success (Aliber \& Hall, 2012; Kubheka, 2015). Contributing to this little success is the design of the support that seems to be less suitable for subsistence farmers. Empowering rural communities with technology that is expensive to maintain hardly addresses the challenges of the resource poor farmers. This has been evidenced in the Massive Food Production Programme (MFPP) and Siyazondla Food Security Programme (SFSP) implemented in the Eastern Cape Province to stimulate black commercial farmers and achieve household food security (Fischer \& Hajdu, 2015). The SFSP is largely managed by the elderly and mostly

\footnotetext{
${ }^{1}$ M.Sc.Agric. Student, Department of Agricultural Economics and Extension, University of Fort Hare, Alice, South Africa. E-mail: siphezantsi@yahoo.com

${ }^{2}$ Professor, Department of Agricultural Economics and Extension, University of Fort Hare, Alice, South Africa. E-mail: ben@benbester.co.za
} 
women (Blaai-Mdolo, 2009). A positive correlation between rural food security and animal traction $^{3}$ was noted in Manzana (2014) and Simalenga et al (2000).

Animal traction ${ }^{4}$ has always been a reliable and relevant tool for subsistence farming. However, with the invention of tractors, it has been perceived by many, including researchers, government officials, and policy makers, as backwards, hence it receives very little attention (Starkey, Jaiyesimi-Njobe \& Hanekom, 1995). Despite the negative perception and negligence of animal traction, the fact remains that subsistence farming still exists and some still use it. Furthermore, there have been increasing numbers of households engaged in subsistence farming.

Therefore, this article addresses two objectives. Firstly, it aims to revisit the known but forgotten benefits of draught power and relate them to subsistence farmers in Ndabakazi villages. The second objective is to recommend types of animal draught power for subsistence farmers in Ndabakazi.

\section{LITERATURE REVIEW}

This section reviews subsistence farming and animal traction literature in South Africa. In doing so, it outlines the state of subsistence farming, its benefits to households, as well as its challenges. It also provides a background of animal traction and how it benefits rural households in general.

\subsection{State of subsistence farming in South Africa}

According to the 2016 Community Survey (CS), there are more than two million agricultural households in South Africa (StatsSA, 2016). Furthermore, the CS shows that there has been a decline in the number of smallholder farmers. Despite this drop, the number of smallholders has been increasing over time. As such, as the population increases, the smallholder farmers follow a similar trend. For example, Coetzee (2003) reported that there were 2.1 million smallholder farmers, while the 2007 Labour Force Survey showed an increment reporting that there were 2.5 million households engaged in farming activities. In contrast, Vink and Van Rooyen (2009) reported that there were approximately 1.3 million smallholder farmers.

It is apparent that these figures are far from consistent, emanating from the lack of reliable and quality data on smallholder farming which has always been a drawback and is still a challenge (Binswanger-Mkhize, 2014; Liebenberg, 2013). Therefore, the exact number of smallholder farmers in the country is quite difficult to determine. Furthermore, there is a general agreement from a couple of authors (Fenyes \& Meyer, 2003; Pienaar \& Von Fintel, 2014) that smallholders are mostly found in the former homelands. However, the smallholder farming in South Africa is very complex.

\footnotetext{
${ }^{3}$ Animal traction is the use of animals (cattle, donkeys, horses, mules, etc.) to carry out agricultural tasks such as ploughing, planting, pulling carts that transport goods, and other relevant tasks.

4 The terms 'animal traction' and 'animal draught power' are used interchangeably in this article.
} 


\subsubsection{Typologies of smallholder farming}

These smallholder farmers, however, are not a homogeneous group as they are often referred to in some literature. For example, the terms 'emerging farmer', 'subsistence farmer', or 'resource-poor farmer' are used interchangeably in the literature as noted by Cousins (2010) as well as Kirsten and Van Zyl (1998). Smallholders in South Africa can be categorised into three broad groups (Nieuwoudt, 2000; Van Averbeke \& Mohamed, 2006). The first is the subsistence orientated group and is the majority group. These are mainly households farming for either main or additional source of food on small areas of land. They are mostly female and elderly, and are located in the former homelands (Pienaar \& Traub, 2015). This group forms the main focus of this research. The second group is made up of the semi-commercial orientated smallholders, termed 'emerging smallholders', who have a desire to fully commercialise their production. This group mainly farms for obtaining an extra source of income and use small proportions of the produce for their own home consumption (Cousins, 2013). The last is a minority group, consisting of fully commercialised smallholders called 'commercial smallholders'.

\subsubsection{Small land holdings}

The nature of land tenure in South African rural areas is under communal ownership. Table 1 provides a summary of land holdings amongst the smallholder farmers. It shows that more than $56 \%$ of smallholders own less than 0.5 hectares of land, while less than $1 \%$ of smallholders own land between 10 and 20 hectares in size. Vink and Van Rooyen (2009) also provided the estimates of land distribution amongst smallholders which shows a similar trend.

Table 1: Distribution of land amongst smallholder farmers in South Africa

\begin{tabular}{|c|c|}
\hline Land size in hectares & Percentage (\%) \\
\hline Less than $\mathbf{0 . 5}$ & 56.82 \\
\hline $\mathbf{0 . 5 - 1}$ & 7.05 \\
\hline $\mathbf{1 - 2}$ & 2.30 \\
\hline $\mathbf{2 - 5}$ & 0.56 \\
\hline $\mathbf{5 - 1 0}$ & 0.03 \\
\hline $\mathbf{1 0 - 2 0}$ & 0.10 \\
\hline Communal grazing land & 31.96 \\
\hline
\end{tabular}

Source: Adapted from Piennar and Von Fintel (2014)

\subsubsection{Significance of smallholder farming}

Critics, including Sender and Johnston (2004), view smallholder subsistence farming as a waste of resources since they argue that it is not viable or sustainable in poverty reduction. Despite this, there is also empirical evidence that households who are involved in farming activities experience hunger less than those who are not (Rogan \& Reynolds, 2018). Furthermore, Aliber and Hart (2009) argued that the consistent number of households continuing to engage in subsistence farming shows its worth to household food security. Subsistence farming has an advantage over commercially orientated smallholder farming since less resources are invested for a reasonable extra income source backed by other income sources. Therefore, the risk is lower compared to their commercial orientated counterparts (Aliber \& Hart, 2009). Although subsistence farming is significant for rural food security, productivity is very low. 


\subsubsection{Low productivity}

Liebenberg (2013) provides some insights into the productivity of smallholders in South Africa, citing poor performance. He estimated the share of black crop farming to be between $3 \%$ and $4 \%$ of the national output. Furthermore, empirical evidence from the literature supports this notion of low productivity amongst smallholder farmers, especially the subsistence farmers, as they can hardly support themselves through farming only (Aliber \& Mdoda, 2015; Baiphethi \& Jacobs, 2009).

Table 2 portays measured maize yields in one of the Trainskei villages in Willowvale. In the Eastern Cape's former Transkei region, maize is by far the largest planted crop amongst smallholders (Bembridge, 1984; Gilimani, 2005). McAllister (2000) estimates the average maize yield to be around $320 \mathrm{~kg}$ per homestead. However, it should be noted that maize yield may vary from region to region due to a variety of reasons which includes quality of soil, rainfall availability, and methods of cultivation. Nevertheless, these figures provide an idea of how production is in the homelands and that production is relatively low compared to the commercial sector.

Table 2: Measured maize yields in Shixini Transkei from 1996/7

\begin{tabular}{|c|c|c|c|}
\hline Homestead/Household & $\begin{array}{c}\text { Cultivated area in } \\
\mathbf{m}^{\mathbf{2}}\end{array}$ & Yield in kg & Kg per hectare \\
\hline MY & 1346 & 632.4 & 4698 \\
\hline MS & 7964 & 3730.8 & 4683 \\
\hline NQ & 5300 & 2402.2 & 4532 \\
\hline NA & 5458 & 1735.9 & 3180 \\
\hline HG & 13892 & 3813.9 & 2727 \\
\hline MG & 3742 & 881.1 & 2097 \\
\hline NT & 6091 & 1374.9 & 2257 \\
\hline SK & 3912 & 818.6 & 2092 \\
\hline NL & 5614 & 1053.4 & 1875 \\
\hline MN & 4212 & 744.2 & 1767 \\
\hline NF & 2852 & 393.5 & 1379 \\
\hline GD & 8891 & 1194.2 & 1343 \\
\hline NK & 20252 & 2560.9 & 1266 \\
\hline MP & 3544 & 437 & 1243 \\
\hline GL & 4358 & 330.6 & 758 \\
\hline
\end{tabular}

Source: McAllister (2000)

\subsection{Animal traction in South Africa}

Animal traction in South Africa dates back to the Khoi-Khoi, whom the first European settlers met in the Cape. However, it was mainly cattle that were used. It was only later on, after the arrival of Jan Van Riebieck and the Dutch East India Company in 1652, that the first horses and donkeys were imported into the country (Joubert, 1995). In the 17th and 18th centuries, 
animal traction was widely adopted in the country for pulling various activities up until the 20th century with the invention of mechanical power (Joubert, 1995).

According to Joubert (1995), this invention was later developed into tractors and that is when the wide adoption amongst the large scale farmers took place (1935-1960). He further highlights that animal traction was mostly used by those with smaller areas of land. However, the use of animal traction eventually declined due to a reduction in the number of animals, which is attributed to a shortage of grazing land caused by betterment schemes. A survey conducted by the South African Network of Animal Traction (SANAT) team in 1994 found that $40-80 \%$ of South African smallholders were still using animals for cultivation and transportation. The survey further showed that cattle were the most used animals for draught power in the Transkei (Starkey et al, 1995).

\subsubsection{Importance of animal traction to smallholder farming}

Animal draught power has many benefits for the smallholder farming sector. Animal draught power is specifically important to smallholders through achieving food security as they assist directly in food production (Food and Agriculture Organisation (FAO), 2010). In doing so, it helps in ploughing, planting and weeding. In addition, sometimes the same animals are used to generate milk, meat, manure and offspring. Furthermore, animal draught power helps in transportation of inputs, outputs and goods where motor vehicles cannot go; as is the case for rural areas of South Africa characterised by poor infrastructure such as poor road conditions (Khapayi \& Celliers, 2016).

Besides agriculture, animal draught power helps in carrying out domestic household chores and saves time. For example, it helps in transporting water, fuel wood, reducing drudgery (especially for women and children), and saves time which can be used for other productive tasks (Simalenga \& Joubert, 1997). Animal traction is also environmentally-friendly and sustainable. Ploughing, planting and weeding with animals reduces the amount of fossil fuel burning, thus reducing the impact of global warming and climate change (FAO, 2010). Global warming and climate change are serious challenges facing the world, including South Africa. Animal draught power encourages crop-animal integrated farming systems. Using kraal manure also reduces the chances of pollution while improving soil fertility and sustainability.

\subsubsection{State and impact of animal traction to South African smallholders}

Despite the limited research on animal traction in South Africa, some research has been done to portray the benefits of animal traction for smallholder farmers (Manzana, 2014; Simalenga et al, 2000; Simalenga \& Joubert, 1997; Starkey et al, 1995). Furthermore, while animal traction is losing its popularity in South Africa, there is a significant number of smallholders who still use it. In 1994, a nation-wide survey showed that 40-60 \% of smallholders were still using animal traction (Starkey et al, 1995). In addition, a survey conducted in the former Ciskei region of the Eastern Cape found that $80 \%$ of smallholders still use animal traction (Simalenga et al, 2000). Recently, Shackleton and Hebinck (2018) found that in Gatyana-Willowvale, most of the farming households use oxen traction to plough their fields.

Starkey et al (1995) further narrates that within the Eastern Cape Province, most smallholders used tractors to plough, whilst animals were used to plant, weed crops, and for the transportation of inputs and outputs. Moreover, cattle, donkeys and mules have been widely 
used in the Eastern Cape (Starkey et al, 1995). Not only was the use of animal traction by smallholders documented, but it was also proven that animal traction use is profitable and costeffective for smallholder farming (Simalenga et al, 2000). Manzana (2014) has also added empirical evidence on how animal traction is contributing to food security amongst smallholders. Moreover, if food is produced at low costs by smallholders, this may result in surplus being sold at affordable prices, providing other non-farming household with cheaper access to food. Although animal draught power has many benefits for subsistence smallholders, it is not without challenges.

\subsubsection{Challenges}

Animal draught power across the globe is perceived as old technology and less relevant for today's lifestyle (FAO, 2010). This is shown by the limited attention it gets from researchers, development practitioners and education institutions. Very little research is done in South Africa on animal traction, despite the establishment of the SANAT (Joubert, 2016). For example, in South African university curriculum for agricultural extension candidates, there is little or no modules for animal power. This is one of the reasons for why there is a lack of reliable statistics on animal traction research. Furthermore, the media also has a hand in the negative perception of animal traction, as it always shows motorised power as the best solution for all farming avenues. The following are also the most cited challenges for using animal power: lack of spares, human capacity to train animals, and animals being in poor condition at the time of ploughing (FAO, 2010; Starkey et al, 1995).

\subsection{Role of agricultural extension to smallholder development}

Davis (2008) defines agricultural extension as "the entire set of organisations that support and facilitate people engaged in agricultural production to solve problems and to obtain information, skills and technology to improve their livelihood and well-being". One of the roles of agricultural extension is to transfer skills, knowledge and information to farmers to improve their livelihood. Most of the extension services in South Africa is provided by the government, especially to smallholder farming. However, there is overwhelming evidence that agricultural extension services in South Africa are failing to fulfil its role due to the incompetence of extensionists (Worth, 2008), lack of resources, low ratio of extensionists to farmers, and poorly defined target groups (Lukhalo, 2017). Given the above points, agricultural extension plays an important role in the development of smallholder farmers. One way of doing that is to provide advice on appropriate technology, skills and information that match the objectives and characteristics of the farmer.

\section{STUDY AREA, DATA AND APPROACH}

This study was conducted in Ndabakazi villages in Butterworth in the Eastern Cape's former Transkei area to gather data on income sources, demographic information and farming activities. Within Ndabakazi, which is a complex of six villages, four villages (Ejojweni, Lengeni, Komkulu and Mziteni) were chosen for the survey. Ndabakazi is located $10 \mathrm{~km}$ from Butterworth town in the direction of East London.

Butterworth falls within Mnquma Local Municpality, which is comprised of Kentane, Ngqamakhwe and Butterworth. In Mnquma Local Municipality, there are 69732 households. Of those households, 38300 households practice some form of agriculture. Half of the 
households (51\%) keep livestock, while $15.4 \%$ produce crops, and $32 \%$ have both crops and livestock (StatsSA, 2011).

A sample of 80 respondents were randomly selected and interviewed for this research. Four villages (20 respondents in each village) were randomly selected. Semi-structured questionnaires were used to collect information from household heads using the local language IsiXhosa to enhance the response rate. Furthermore, focus group discussions were used to supplement the information obtained from the household survey. The focus groups consisted of eight household heads each as smaller groups are easier to manage where everyone has a chance to engage in the discussion.

Moreover, the data collected in this study was analysed using descriptive statistics such as means, standard deviations and range. One way of highlighting the importance of animal draught power to subsistence farming is a cost-benefit analysis or a comparison study, however, none were possible with the available data. Finally, this study aims to demonstrate the need and relevance of animal draught power for subsistence farmers using the case of Ndabakazi.

\section{RESULTS AND DISCUSSION}

\subsection{Socio-economic characteristics of the sample households}

The survey results reveal that the majority of the household heads in Ndabakazi are pensioners, in other words, persons over the age of 60 . Furthermore, in all four villages, many respondents fall into the " $60+$ " age group followed by the middle age range which is between the ages of "50-59" and "40-49" as shown in Table 3. The remainder, the smallest group, had the age range "30-39" and it accounted for only $4 \%$ of the sample. The household heads' gender distribution is dominated by females (63\%), where males accounted for only $37 \%$ of the respondents. The average household size was five persons per household with the largest household comprising of eight persons and the smallest household with only one person.

Table 3: Household head age in years

\begin{tabular}{|c|c|c|c|c|c|c|}
\hline \multirow{2}{*}{$\begin{array}{c}\text { Age } \\
\text { category }\end{array}$} & \multicolumn{4}{|c|}{ Village } & \multirow[t]{2}{*}{ Total } & \multirow[t]{2}{*}{$\%$} \\
\hline & Ejojweni & Komkhulu & Lengeni & Mziteni & & \\
\hline $30-39$ & 0 & 0 & 1 & 2 & 3 & $4.0 \%$ \\
\hline $40-49$ & 3 & 3 & 4 & 4 & 14 & $17.4 \%$ \\
\hline $50-59$ & 3 & 4 & 5 & 3 & 15 & $18.6 \%$ \\
\hline$\geq 60$ & 4 & 13 & 10 & 11 & 48 & $60.0 \%$ \\
\hline $\mathbf{N}$ & 20 & 20 & 20 & 20 & 80 & $100 \%$ \\
\hline
\end{tabular}

\subsection{Land access}

Results from Ndabakazi show that every household has at least access to land both for arable crop production and shared grazing, although the majority has access to less than a hectare (Figure 1). These findings are in line with those reported by Perret (2000) on a provincial level. She reported that $85 \%$ of rural households in the Eastern Cape have access to arable land while $75 \%$ have access to shared grazing land. All the surveyed households in Ndabakazi have at least access to land as shown in Figure 1. 


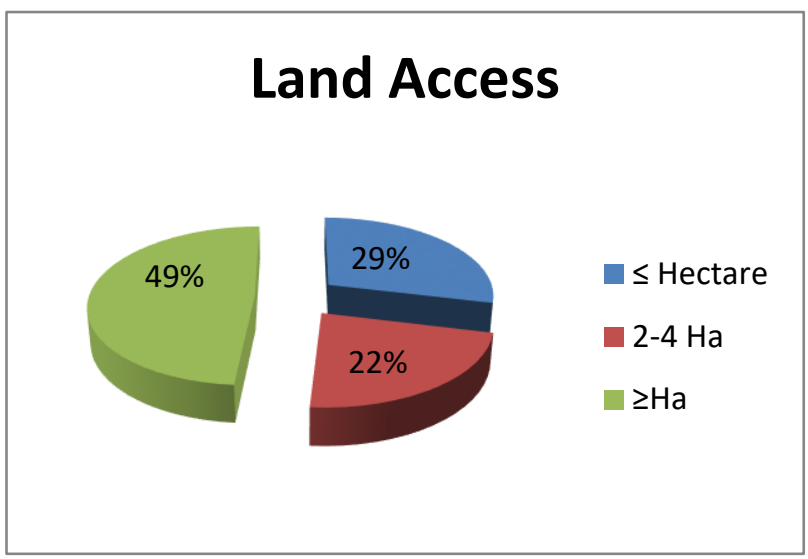

\section{Figure 1: Land access}

\subsection{Arable land production}

While all the surveyed households have access to land, arable cultivation was only limited to gardens $^{5}(71 \%)$, not the arable fields as shown in Figure 2. Furthermore, there are some households who do not cultivate neither gardens nor fields. In this respect, there is quite a large body of knowledge on the declining rural household arable farming (Andrew \& Fox, 2004; De La Hey \& Beinart, 2016; Ngcaba, 2002).

\section{Cultivation of gardens}

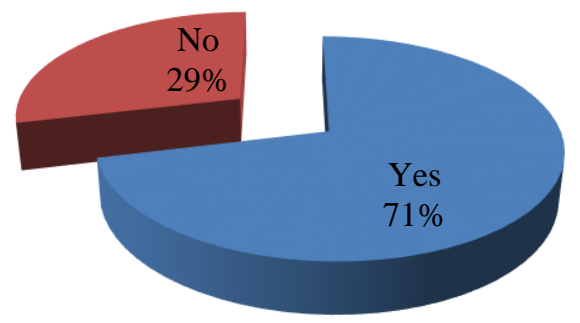

\section{Figure 2: Share of garden cultivators}

\subsubsection{Produced crops and yields}

Table 4 portrays the yields of major produced crops in Ndabakazi villages. Maize is the most produced crop in Ndabakazi. This is in line with what Bembridge (1984) found in the Qumbu, Emgcwe and Qamata rural areas of the former Transkei. Furthermore, Perret et al (2000) also found the same result in Tsomo, Mount Fletcher and Nyandeni in the Transkei. Later, Gilimani (2005) also reached the same conclusion.

\footnotetext{
${ }^{5}$ A garden is a piece of arable land adjacent to the homestead, while a field is arable land which is normally larger than the garden but away from the homestead.
} 
Rural households in Ndabakazi produce an average of $150 \mathrm{~kg}$ of maize per garden in a year. This is equivalent to three $50 \mathrm{~kg}$ bags of maize. The highest producing household produced $10 \times 50 \mathrm{~kg}$ bags, while some who produced in small gardens had a yield of $25 \mathrm{~kg}$ of maize. These may not necessarily be the exact quantities due to the nature of production in rural households. The respondents do not keep records of production formally, but rather they relate their produce to $50 \mathrm{~kg}$ bags and buckets. These figures exclude green maize so in actual terms they may be slightly higher than those reported. This indeed shows that subsistence farming contributes to food security as most of these produced crops in Ndabakazi are staple food for many poor households.

Besides arable production, Ndabakazi households also keep animals. The main livestock kept are cattle, sheep, goats, pigs and poultry. The most commonly kept stock is indigenous chickens (64\%), followed by goats (46\%), pigs (38\%), cattle (36\%), and sheep (29\%).

Table 4: Average crop yields in kilograms per garden

\begin{tabular}{|c|c|c|c|c|c|}
\hline \multicolumn{7}{|c|}{ Average crop yield in kgs/garden6 } \\
\hline Crop & n & Min & Max & Mean & Range \\
\hline Maize & 57 & 25 & 500 & 150 & 475 \\
\hline Potatoes & 53 & 30 & 100 & 61.76 & 70 \\
\hline Cabbage & 53 & 10 & 50 & 21.32 & 40 \\
\hline Beans & 57 & 5 & 50 & 25.36 & 45 \\
\hline
\end{tabular}

\subsection{Crop production cost}

Table 5 shows production costs incurred by Ndabakazi households. On arable production they spend an average of R2 308 per production season. Furthermore, ploughing and weeding costs, which were incurred by 49 households out of the 57 that cultivates gardens, make up $57 \%$ of the production costs. The cost of hiring a tractor for ploughing at the time the data was collected was R350 per garden regardless of size. The cost of hiring labour for weeding was R50 per day per person working from $08 \mathrm{~h} 00$ to $16 \mathrm{~h} 00$. In addition to these costs, some households purchase inorganic fertilisers. This highlights the high production costs incurred by these farming households. In such instances, animal traction could play a crucial role, for example, had these households used animals to plough and weed the crops, they could have saved up to $57 \%$ of their production costs.

Table 5: Average crop production cost

\begin{tabular}{|c|c|c|c|c|c|}
\hline \multicolumn{7}{|c|}{ Production cost in Rands/ garden cultivated } \\
\hline Item & $\mathbf{N}$ & Range & Minimum & Maximum & Mean \\
\hline Ploughing & 49 & 350 & 350 & 700 & 388 \\
\hline Fertilization & 15 & 420 & 30 & 450 & 220 \\
\hline Weeding & 49 & 350 & 150 & 500 & 329 \\
\hline Pesticides & 8 & 50 & 150 & 200 & 166 \\
\hline $\begin{array}{c}\text { Seeds and } \\
\text { seedlings }\end{array}$ & 56 & -- & 60 & 500 & 156 \\
\hline Total & & 1610 & 740 & 2350 & 259 \\
\hline
\end{tabular}

\footnotetext{
${ }^{6}$ Note that garden size in the sample varies with household.
} 


\section{CONCLUSION AND RECOMMENDATIONS}

The main objective of this article was to revisit the known benefits of animal traction and relate them to the case of subsistence farmers in Ndabakazi villages. The other objective was to make recommendations on which animal draught power to be used in this case studied here.

Ndabakazi subsistence farmers are generally old aged women who have access to small pieces of land - less than half a hectare. Furthermore, there is at least some pull of family labour, but cattle are very few. The staple food crops produced by the households in Ndabakazi has at least some contribution to household food security although it is reduced by high production costs, particularly ploughing and weeding costs. The high cost of production was also witnessed by garden cultivating households who relied on tractors in Gatyana (Shackleton \& Hebinck, 2018). Given this state of production in Ndabakazi subsistence households, animal draught power can play a critical role in enhancing production by reducing crop production costs, moreover, it can also stimulate more production. Therefore, it is concluded that animal traction is still relevant to subsistence farmers such as those in Ndabakazi villages.

Adoption of donkeys, horses and mules for ploughing, planting and weeding is recommended for rural households such as those from Ndabakazi for two reasons. Firstly, these animals have a longer lifespan (donkeys: 25years, mules: 35 years) than cattle. Secondly, they also require less labour and donkeys can be easily handled by women and adapt well in harsh conditions (Simalenga \& Joubert, 1997). In addition, in Ndabakazi villages, animals graze on an open (not fenced) grazing system, animals wander all around, and young boys fetch them in the evenings. In this regard, horses are recommended to save time and loss of animals. Agricultural extension has an important role in achieving these recommendations and transferring knowledge and necessary skills to subsistence smallholders. For agricultural extension to play an effective role to subsistence farming, a sound understanding of the environment in which these farmers operate is a prerequisite.

These recommendations can be useful in other similar settings as in Ndabakazi villages, to individual households as well as small community projects such a community food gardens. A typical example is Siyazondla Homestead Food Production Programme of the Eastern Cape Department of Agriculture, which according to Blaai-Mdolo (2009), is largely managed by the elderly and women. Finally, given the widespread of subsistence farming in South Africa, it is recommended that agricultural extension should incorporate animal traction training in their skills set. This paper has shown how animal draught power benefits are still relevant to subsistence smallholders in Ndabakazi villages. Thus, future studies can look at other regions and in-depth analyses of why animal traction has low adoption amongst subsistence farmers, yet it has relevant benefits.

\section{ACKNOWLEDGEMENTS}

The authors would like to thank the financial assistance of the Levenstain Family Bursary Trust in data collection. We are also grateful to Dr Gabriele Mack for her comments in earlier drafts of this article. 


\section{REFERENCES}

ALIBER, M. \& HALL, R., 2012. Support for smallholder farmers in South Africa: Challenges of scale and strategy. Dev. South. Afr., 29(4):584-562.

ALIBER, M. \& HART, T.G.B., 2009. Should subsistence farming be supported as a strategy to address rural food insecurity? Agrekon, 48(4):434-458.

ALIBER, M. \& MDODA, L., 2015. The direct and indirect economic contribution of smallscale black agriculture in South Africa. Agrekon, (54)2:18-37.

ANDREW, M. \& FOX, R.C., 2004. 'Undercultivation' and intensification in the Transkei: A case study of historical change in the use of arable land in Nompa, Shixini. Dev. South. Afr., 21(4):687-706.

BAIPHETHI, M.N. \& JACOBS, P.T., 2009. The contribution of subsistence farming to food security in South Africa. Agrekon, 48(4):459-582.

BEMBRIDGE, T.J., 1984. A systems approach study of agricultural development problems in Transkei. PhD Thesis, University of Stellenbosch.

BINSWANGER-MKHIZE, H.P., 2014. From failure to success in South African land reform. Afr. J. Agr. Resour. Econ., 9(4):253-269.

BLAAI-MDOLO, B., 2009. The green revolution and poverty alleviation: Challenges faced by women in small-scale agriculture, an investigation into Siyazondla Homestead Food Production Programme, Mbashe Local Municipality, Eastern Cape. M Thesis, University of Fort Hare.

COETZEE, G., 2003. Agricultural finance in South African agriculture. In The challenge of change: Agriculture, land and the South African economy (pp.225-242). Pietermaritzburg: University of Natal Press.

COUSINS, B., 2010. What is a smallholder? Class-analytic perspective on small-scale farming and agrarian reform in South Africa. In Reforming land and resource use in South Africa (pp.107-127). Cape Town: Routledge.

COUSINS, B., 2013. Small irrigation schemes, agrarian reform and 'accumulation from above and from below' in South Africa. J. Agrar. Change, 13(1):116-139.

DAVIS, K.E., 2008. Extension in Sub-Saharan Africa: Overview and assessment of past and current models, and future prospects. JIAEE., 15(3):15-28.

DE LA HEY, M. \& BEINART, W., 2016. Why have South African smallholders largely abandoned arable production in fields? A case study. J. South. Afr. Stud., 43(4):753-770.

FENYES, T. \& MEYER, N., 2003. Structure and production in South African agriculture. In The challenge of change: Agriculture, land and the South African economy. Pietermaritzburg: University of Natal Press.

FISCHER, K. \& HAJDU, F., 2015. Does raising maize yields lead to poverty reduction? A case study of the Massive Food Production Programme in South Africa. Land Use Policy, 46:304-313.

FOOD AND AGRICULTURE ORGANISATION OF THE UNITED NATIONS (FAO), 2010. Draught animal power: An overview. Available from: http://www.fao.org/fileadmin/user_upload/ags/publications/draugth_ap_overview.pdf 
GILIMANI, B.M., 2005. The economic contribution of home production for home consumption for South African agriculture. M Thesis, University of Stellenbosch.

JOUBERT, B., 1995. A historical perspective on animal power use in South Africa. In Animal traction in South Africa: Empowering rural communities (pp.125-138). Gauteng: Halfway House.

JOUBERT, B., 2016. Using animals to plough the fields. Farmer's weekly. Feb,23.

KHAPAYI, M. \& CELLIERS, P.R., 2016. Factors limiting and preventing emerging farmers to progress to commercial agricultural farming in the King William's Town area of the Eastern Cape Province of South Africa. S. Afr. J. Agric. Ext., 44(1):25-41.

KIRSTEN, J.F. \& VAN ZYL, J., 1998. Defining small-scale farmers in the South African context. Agrikon, 37(4):551-562.

KUBHEKA, B.C., 2015. Impact assessment of the Siyazondla Homestead Food Production Programme in improving household food security of selected households in the Amathole District, Eastern Cape. M Thesis, University of KwaZulu Natal.

LIEBENBERG, F., 2013. South African agricultural production, productivity and research performance in the $20^{\text {th }}$ century. PhD Thesis, University of Pretoria.

LUKHALO, T., 2017. An expenditure review of agricultural extension system in South Africa. M Thesis, University of Pretoria.

MANZANA, S., 2014. An assessment of the impact of animal traction on rural household food security: A case of Damane rural community in Cofimvaba in the Eastern Cape Province of South Africa. M Thesis, University of Fort Hare.

MCALLISTER, P.A., 2000. Maize yields in the Transkei: How productive is subsistence cultivation? Occasional Paper No. 14. PLAAS. Cape Town, South Africa.

NIEUWOUDT, W.L., 2000. An economic evaluation of a crop insurance programme for smallscale commercial farmers in South Africa. Agrekon, 39(3):269-291.

NGCABA, S.V., 2002. The declining agriculture in rural Transkei: The case of Mission Location Butterworth. M Thesis, Rhodes University.

PERRET, S., 2000. Livelihood strategies in rural Transkei (Eastern Cape Province): How does wool production fit in? Working Paper 20/2002. University of Pretoria, South Africa.

PERRET, S., CARSTENS, J., RANDELA, R. \& MOYO, S., 2000. Activity systems and livelihoods in Eastern Cape Province rural areas (Transkei): Household typologies as socio-economic contribution to a Landcare Project. Working Paper 07/2000. University of Pretoria, South Africa.

PIENAAR, L. \& TRAUB, L., 2015. Understanding the smallholder farmer in South Africa: Towards a sustainable livelihood classification. Paper presented to The International Conference of Agricultural Economics. Rome, Italy.

PIENAAR, L. \& VON FINTEL, D., 2014. Hunger in the former apartheid homelands: Determinants of convergence on a century after the 1913 land act. Agrekon, 53(4):38-67.

ROGAN, M. \& REYNOLDS, J., 2018. Meeting food security needs in very poor households in the Eastern Cape: The role of own agricultural production. Available from: www.econ3x3.org/sites/default/files/articles/Rogan $\% 20 \% 26 \% 20$ Reynolds $\% 202018 \% 2$ 0Meeting\%20food\%20security\%20needs\%20in\%20Eastern\%20Cape\%20FINAL.pdf 
SENDER, J. \& JOHNSTON, D., 2004. Searching for a weapon of mass production in rural Africa: Unconvincing arguments for land reform. J. Agrar. Change, 4(1-2):142-164.

SHACKLETON, S.E. \& HEBINCK, P., 2018. Through the 'thick and thin' of farming on the Wild Cost South Africa. J. Rural Stud., 61:277-289.

SIMALENGA, T.E. \& JOUBERT, A.B.D., 1997. Developing agriculture with animal traction. Pretoria: DAFF.

SIMALENGA, T.E., BELETE, N.A., MZELENI, N.A. \& JONGISA, L.L., 2000. Profitability of using animal traction under smallholder farming conditions in Eastern Cape, South Africa. S. Afr. J. Agric. Ext., 29(1):1-9.

STARKEY, P., JAIYESIMI-NJOBE, F. \& HANEKOM, D., 1995. Animal traction in South Africa: Overview of key issues. In Animal traction in South Africa: Empowering rural communities (pp.17-30). Gauteng: Halfway House.

STATISTICS SOUTH AFRICA (StatsSA), 2007. Labour force survey. Available from: https://www.datafirst.uct.ac.za/dataportal/index.php/catalog/139

STATISTICS SOUTH AFRICA (StatsSA), 2011. Census 2011. Available from: http://www.statssa.gov.za/?page_id=3839

STATISTICS SOUTH AFRICA (SatsSA), 2016. Community survey. Available from: www.statssa.gov.za/publications/03-0105/Presentation_CS2016_Agricultural_Households.pdf

VAN AVERBEKE, W. \& MOHAMED, S.S., 2006. Smallholder farming styles and development policy in South Africa: The case of Dzindi Irrigation Scheme. Agrekon, 45(2):136-157.

VINK, N. \& VAN ROOYEN, J., 2009. The economic performance of agriculture in South Africa since 1994: Implications for food security. Working Paper 17. DBSA Development Planning Division, South Africa.

WORTH, S.H., 2008. An assessment of the appropriateness of agricultural extension education in South Africa. PhD Thesis, University of KwaZulu-Nata 
